\title{
The impact of nitrogen fertilizer use on greenhouse gas emissions in an oil palm plantation associated with land use change
}

\author{
FARADIELLA MOHD KUSIN \\ Department of Environmental Sciences and Environmental Forensics Research Centre, Faculty of Environmental \\ Studies, Universiti Putra Malaysia, 43400 UPM Serdang, Malaysia \\ Corresponding author: e-mail: faradiella@upm.edu.my
}

NURUL IZZATI MAT AKHIR

Department of Environmental Sciences, Faculty of Environmental Studies, Universiti Putra Malaysia, 43400 UPM

Serdang, Malaysia

FERDAUS MOHAMAT-YUSUFF

Department of Environmental Sciences and Environmental Forensics Research Centre, Faculty of Environmental Studies, Universiti Putra Malaysia, 43400 UPM Serdang, Malaysia

MUHAMAD AWANG

SEGi University, Kota Damansara, 47810 Petaling Jaya, Selangor, Malaysia

Received: April 27, 2014; accepted: July 16, 2015

\begin{abstract}
RESUMEN
Se estudian las emisiones de gases de efecto invernadero relacionadas con el cambio de uso del suelo en una plantación de palma de aceite específica. Se analizaron las emisiones de óxido de nitrógeno $\left(\mathrm{N}_{2} \mathrm{O}\right)$ procedentes de la aplicación de fertilizantes nitrogenados durante la etapa de cultivo en palmeras de diferentes edades dentro de la plantación. La emisión de $\mathrm{N}_{2} \mathrm{O}$ varía de 19.11 a $22.17 \mathrm{~kg}$ de $\mathrm{N}_{2} \mathrm{O}-\mathrm{N} / \mathrm{ha}$, lo que resulta en la emisión de 1052.26-1209.51 kg de $\mathrm{CO}_{2}$-eq/ha. Sin embargo, no se encontró una relación evidente entre las emisiones de $\mathrm{N}_{2} \mathrm{O}$ o $\mathrm{CO}_{2}$-eq y la edad de las palmeras. Por otra parte, también se evaluó el impacto del cambio de uso del suelo en el desarrollo de la plantación mediante la evaluación de variaciones en las existencias de carbono dentro de la plantación. La conversión de finca cauchera a plantación de palma de aceite libera el contenido de carbono en el suelo (i.e., produce emisión de carbono), pero dicho fenómeno está previsto en la literatura. En conjunto, las emisiones relacionadas con el fertilizante y las vinculadas con el combustible durante la etapa de cultivo contribuyen con alrededor de 79 y $21 \%$, respectivamente, de la emisión total de gases de efecto invernadero de la plantación. Por lo tanto es probable que la aplicación de fertilizantes nitrogenados incremente las emisiones resultantes de la transformación de finca cauchera a plantación de palma de aceite, pero los valores se encuentran dentro de los límites estimados para una plantación de palma de aceite en Malasia.
\end{abstract}

\section{ABSTRACT}

The emissions of greenhouse gases (GHGs) in an oil palm plantation associated with land use change have been evaluated on a site-specific basis. Nitrous oxide $\left(\mathrm{N}_{2} \mathrm{O}\right)$ emissions from the application of nitrogen fertilizers during the growth stages of the palm oil were analyzed for palms of different ages within the plantation. The $\mathrm{N}_{2} \mathrm{O}$ release ranges between 19.11-22.17 kg of $\mathrm{N}_{2} \mathrm{O}-\mathrm{N} / \mathrm{ha}$, resulting in the emission of 1052.26-1209.51 kg of $\mathrm{CO}_{2}$-eq/ha. However, there is no clear relationship between the emissions of $\mathrm{N}_{2} \mathrm{O}$ or $\mathrm{CO}_{2}$-eq and the age of the oil palms. On the other hand, the impact from land use change for the development of the site was also evaluated by assessing the emissions from carbon stock changes within the plantation. The transformation 
of a rubber estate into an oil palm plantation loses the soil carbon content (i.e., release of carbon emissions). However, this phenomenon has been anticipated in literature. Overall, fertilizer-related emissions and fuel emissions during the growth stages contribute to about 79 and $21 \%$, respectively, of the total GHG emissions from the plantation. Therefore, it is likely that the application of nitrogen fertilizer may increase the existing carbon emission from the conversion of rubber to oil palm plantation, but the values are within the estimated for a Malaysian oil palm plantation.

Keywords: Carbon stock changes, global warming, greenhouse gas emission, nitrous oxide, nitrogen fertilizer, oil palm plantation.

\section{Introduction}

The establishment of oil palm plantations in Malaysia has rapidly expanded in the past 25 years, especially in the west coast of the Malaysian Peninsula, where soil is most fertile and productive (Henson, 2005). Oil palm has been extensively planted in parts of East Malaysia on newly explored forest land. Generally, oil palm plantations in this country have been developed from logged-over, degraded forest and also as replacement of other crops such as rubber, coconut and cocoa, since these crops have become less profitable than oil palm (MPOB, 2001; Henson, 2004). Greenhouse gases (GHG) emissions from land use change are regularly debated, particularly in relation to biofuels (e.g., establishing new plantations on agricultural land). Emissions are in particular related to changes in aboveground and belowground biomass, as well as soil organic matter (Brinkmann Consultancy, 2009). Specifically, the establishment and operation of a new plantation lead to the removal of the original aboveground and belowground carbon stocks (e.g., forest, grassland, etc.). On the other hand, a plantation stores carbon through the growth of oil palms.

Oil palm is a perennial crop. There are few important phases in its life cycle, beginning from the agricultural phase (establishment and growth of the plantation) through the oil extraction phase (Castanheira et al., 2014). The growth stages of oil palm include activities related to the development of this plant, whereby typically three stages are considered throughout its lifetime, i.e. nursery, immature plantation and mature plantation (Schmidt, 2007). It is believed that the most significant contribution to global warming from an oil palm plantation is from the agricultural stage, i.e. cultivating $(15 \%)$, clearing (17\%) and replanting (18\%) (Schmidt, 2010). The emissions arising from operations during oil palm growth and fresh fruit bunches (FFBs) processing are in particular related to the use of fossil fuels for internal transport and machinery, fertilizers, fuels for the palm oil mill, and emissions from the palm oil mill effluent (POME) (Brinkmann Consultancy, 2009).

Common inputs of oil palm fertilizers comprise nitrogen fertilizers (i.e., ammonium nitrate, ammonium sulphate, urea and ammonium chloride), phosphate rock, potassium chloride and kieserite. The emissions released may vary between the type of fertilizers and the mode of production. Specifically, GHG emissions related to the use of fertilizers in an oil palm plantation include nitrous oxide $\left(\mathrm{N}_{2} \mathrm{O}\right)$ emissions from the application of nitrogen fertilizers. According to the Intergovernmental Panel on Climate Change (IPCC) guidelines, $1 \%$ of $\mathrm{N}_{2} \mathrm{O}-\mathrm{N}$ is emitted from the total $\mathrm{N}$ applied during fertilizer application. Emissions from fertilizer application represent more than $50 \%$ of the overall plantation emissions (Schmidt, 2010; Castanheira et al., 2014). The amount of fertilizer used in an oil palm plantation may result in high $\mathrm{N}_{2} \mathrm{O}$ emission into the atmosphere, ultimately leading to significant global warming (Corley and Tinker, 2003).

$\mathrm{N}_{2} \mathrm{O}$ is a potent greenhouse gas with a global warming potential over a 100-yr. period 298 times higher than carbon dioxide $\left(\mathrm{CO}_{2}\right)$ (IPCC, 2007). Agriculture contributes about $42 \%$ of the increasing $\mathrm{N}_{2} \mathrm{O}$ emission into the atmosphere. $\mathrm{N}_{2} \mathrm{O}$ is produced in agricultural soils by microbial transformation of compounds that contain nitrogen, such as fertilizer and animal dung and urine (Giltrap et al., 2014). Artificial fertilizers are applied to boost the crop's growth (De Datta, 1995). The inputs of N-fertilizer can occur through either direct or indirect pathways. Direct $\mathrm{N}_{2} \mathrm{O}$ emission occurs from direct addition of $\mathrm{N}$-fertilizer on the soil whereas indirect $\mathrm{N}_{2} \mathrm{O}$ emission may results from processes such as $\mathrm{N}$-deposition from the atmosphere, $\mathrm{N}$-fixation by legumes, and decomposition of biomass residues (Schmidt, 2007; Millar et al., 2010). The increase in available mineral $\mathrm{N}$ in soil may enhance the formation 
of $\mathrm{N}_{2} \mathrm{O}$ through the process of nitrification and denitrification and its emission to the atmosphere (Mosquera et al., 2007; Hewitta et al., 2009; Vandermeer et al., 2009). Generally, operations during the growth stages, such as transportation, FFB processing and use of palm oil-derived products may increase $\mathrm{N}_{2} \mathrm{O}$ emissions to the atmosphere (Klaarenbeeksingel, 2009). The focus of this study is mainly on the growth stages of oil palm, in which the GHG emissions of agricultural-related activities were estimated. Additionally, the impact on GHG emissions of land use change resulting from the establishment of an oil palm plantation was evaluated. Therefore, in this study we attempt to evaluate the impact of nitrogen fertilizers on the direct emission of GHG and to incorporate the indirect emission due to the expansion (conversion) of the oil palm plantation from the previous land use on a site-specific basis.

\section{Materials and methods}

\subsection{Study site and data}

The study was conducted at Kempas Estate, an oil palm plantation located in the north of Malacca/ Johor, in the state of Malacca, covering an area of
1700 ha (Fig. 1). The average production of the oil palm plantation, managed and operated by Sime Darby Plantation Malaysia, is $24.11 \mathrm{Mt} /$ ha of FFBs. Kempas Estate land use changed from a previous rubber plantation into an oil palm plantation.

Data of nitrous oxide emissions were estimated from the amount of applied N-fertilizer, obtained from the scheduled fertilizing scheme between 19862009. Other relevant data for estimating N-related emissions were obtained from Schmidt (2007) for average Malaysian oil palm-related emissions. For assessing emissions from oil palms of different ages, data from the year 2012 comparing immature and mature plants was used. Oil palms were classified as immature $(<5$ years $)$ and mature $(>5$ years $)$. The typical life cycle of an oil palm is about 25-30 yrs., then new palms should be replanted (Chase and Henson, 2010). Organic carbon, soil organic matter and other relevant values for estimating the carbon stock were determined experimentally in Mejan (2013). Emissions from fuel use (e.g., for internal transportation within the estate) were determined in Abdullah (2013).

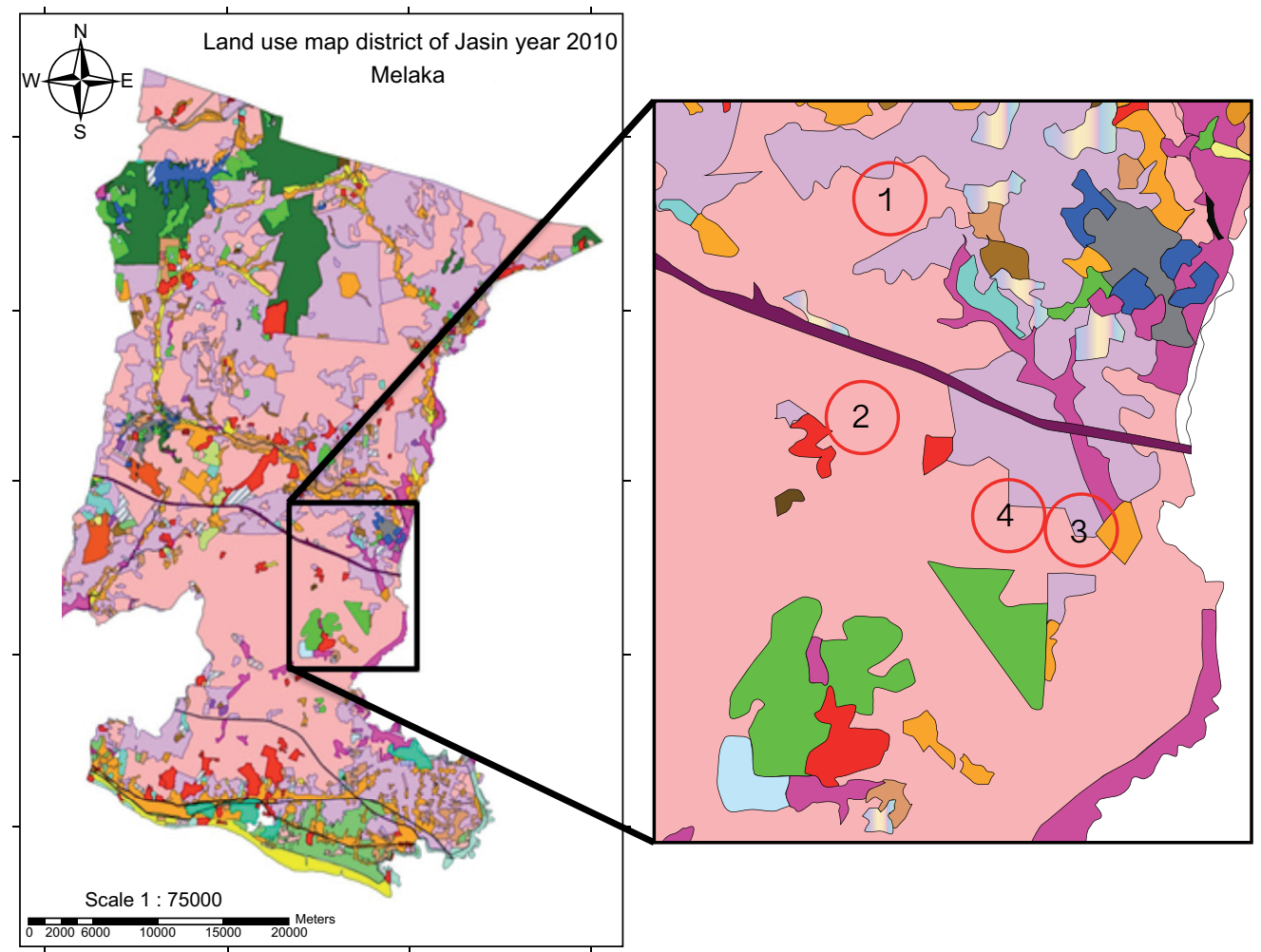

Fig. 1. Kempas Estate. (a) Location of. (b) Distribution: 1, mature palm block ( $>20$ yrs.; 2 , mature palms (15-20 yrs.); 3, mature palms (10-15 yrs.); 4, immature palms ( $<5$ yrs.). 


\subsection{Estimation of GHG emissions and carbon stock changes}

The amount of direct $\mathrm{N}_{2} \mathrm{O}$ emissions from nitrogen fertilizer application in Kempas Estate was estimated by incorporating the type of peat soil, based on the model described by the IPCC. The equation for estimating $\mathrm{N}_{2} \mathrm{O}$ emissions is as follows (IPCC, 2006):

$\mathrm{kg} \mathrm{N} \mathrm{N}_{2} \mathrm{O}-\mathrm{N} / \mathrm{ha}=\left[\left(F_{S N}+F_{O N}+F_{C R}+F_{S O M}\right) \times\right.$

$\left.E F_{1}\right]+\left(F_{O S} \times E F_{2}\right)$

where $F_{S N}$ is the annual amount of synthetic N-fertilizer applied to the soils $\left(\mathrm{kg} \mathrm{N} \mathrm{ha}^{-1}\right) ; F_{O N}$ is the annual amount of organic $\mathrm{N}$-fertilizer applied $\left(\mathrm{kg} \mathrm{N} \mathrm{ha}^{-1}\right)$; $F_{C R}$ is the amount of nitrogen in crop residues (aboveground and belowground) returned to soils annually $\left(\mathrm{kg} \mathrm{N} \mathrm{ha}^{-1}\right) ; F_{\text {SOM }}$ is the annual amount of mineralized $\mathrm{N}$ in mineral soils, in association with loss of soil $\mathrm{C}$ from soil organic matter as a result of changes to land use or management $\left(\mathrm{kg} \mathrm{N} \mathrm{ha}^{-1}\right) ; F_{O S}$ is the area of organic soils cultivated annually (ha); $E F_{1}$ is the emission factor for emissions from $\mathrm{N}$ inputs ( $\mathrm{kg} \mathrm{N}_{2} \mathrm{O}-\mathrm{N} / \mathrm{kg} \mathrm{N}$ input); 0.0125 is the default emission factor used in this study; $E F_{2}$ is the emission factor for emissions from organic soil cultivation $(\mathrm{kg}$ $\mathrm{N}_{2} \mathrm{O}-\mathrm{N} / \mathrm{ha}-\mathrm{yr}$ ); and 16 was used as default emission factor.

$\mathrm{CO}_{2}$ eq is the conversion of other gases such as nitrogen to the equivalent amount of carbon dioxide based on its global warming potential (GWP). In order to calculate $\mathrm{CO}_{2}$ equivalents, standard ratios are used to convert other gases into equivalent amounts of $\mathrm{CO}_{2}$, which describes their total warming impact relative to $\mathrm{CO}_{2}$ over a set period. Emissions were converted into $\mathrm{CO}_{2}$-eqs using the GWP of the gases. According to the IPCC (2006), the equation is as follows:

$\mathrm{CO}_{2 \mathrm{eq}}=\left(F_{S N} \times F_{E 1}\right)(44 / 28)\left(\mathrm{GWP} \mathrm{N} \mathrm{N}_{2} \mathrm{O} / 1000\right)$

where $F_{S N}$ represents the amount of synthetic $\mathrm{N}$-fertilizer applied to soils $\left(\mathrm{kg} \mathrm{N} \mathrm{yr}^{-1}\right) ; F_{E 1}$ is the emission factor for $\mathrm{N}_{2} \mathrm{O}$ emissions from $\mathrm{N}$ inputs $\left(\mathrm{kg} \mathrm{N}_{2} \mathrm{O}-\mathrm{N}\right.$ $\mathrm{kg} \mathrm{N}$ input ${ }^{-1}$ ); 44/28 is a conversion factor of $\mathrm{N}_{2} \mathrm{O}-\mathrm{N}$ emissions to $\mathrm{N}_{2} \mathrm{O}$ emissions; and GWP represents the GWP of $\mathrm{N}_{2} \mathrm{O}\left(\mathrm{t} \mathrm{CO}_{2}\right.$-eq).

The amount of carbon stocks was estimated according to the IPCC guidelines as follows:

$$
\begin{aligned}
& C S=S O C+C_{\text {veg }} \\
& =\left(S O C \times F_{L U} \times F_{M G} \times F_{I}\right)+\left(C_{B M}+C_{D O M}\right)
\end{aligned}
$$

where $C S$ are the carbon stocks; $S O C$ is the soil organic carbon $\left(t \mathrm{Cha}^{-1}\right) ; C_{v e g}$ is the above and belowground vegetation carbon stock ( $\mathrm{tC}$ ha $\left.^{-1}\right) ; C_{B M}$ is the carbon stock in living biomass (above and belowground biomass) $\left(t C \mathrm{ha}^{-1}\right) ; C_{D O M}$ is the carbon stock in dead organic matter $\left(t C \mathrm{ha}^{-1}\right) ; F_{L U}$ is the factor reflecting the difference in $S O C$ associated with land use; $F_{M G}$ is the factor associated with management practice; and $F_{I}$ is the factor associated with different levels of carbon input to soil. The $S O C$ and $C_{D O M}$ values for an oil palm plantation were determined from field experiments. The value of $C_{B M}$ was taken from Brinkmann Consultancy (2009), which is relevant for the Malaysian oil palm industry. The values of $F_{L U}$, $F_{M G}$ and were taken from the IPCC guidelines as 1 , 1.22 and 1 , respectively.

The calculation of carbon stock changes and the resulting $\mathrm{CO}_{2}$-eq emissions were determined according to the IPCC guidelines as:

$$
\begin{aligned}
& \mathrm{CO}_{2}-\mathrm{eq}=\Delta C S \times 44 / 12 \times 1 / 20 \times 1 / \mathrm{P} \\
& =(C S R-C S A) \times 44 / 12 \times 1 / 20 \times 1 / P
\end{aligned}
$$

where $\mathrm{CO}_{2}$-eq is the annualized $\mathrm{CO}_{2}$-eq emission from carbon stock change ( $t \mathrm{CO}_{2}$-eq $\left.t^{-1} P O\right) ; \Delta C S$ are the changes in carbon stocks $\left(t \mathrm{C} \mathrm{ha}^{-1}\right) ; C S_{R}$ is the carbon stock of the reference (previous) land use $\left(\mathrm{t} \mathrm{Cha}^{-1}\right)$; $C S_{A}$ is the carbon stock of the actual land use (oil palm plantation) $\left(t C \mathrm{ha}^{-1}\right)$; and $P$ is the palm oil productivity $\left(t P O \mathrm{ha}^{-1}\right)$.

\section{Results and discussion}

The emissions from carbon stock changes within Kempas Estate were estimated for assessing the impact of land use change in the plantation development. The estate was transformed into an oil palm plantation from a previous rubber plantation area because rubber is no longer a profitable crop compared to oil palm (Henson, 2005). The estimated emissions are presented in Figure 2a, b.

As noted in Figure 2a, b, emissions show positive values regardless of the age of the palms. This indicates that the transformation of land use into an oil palm development increased GHG emissions (although at a relatively low amount). In other words, the transformation into an oil palm plantation from rubber estate 


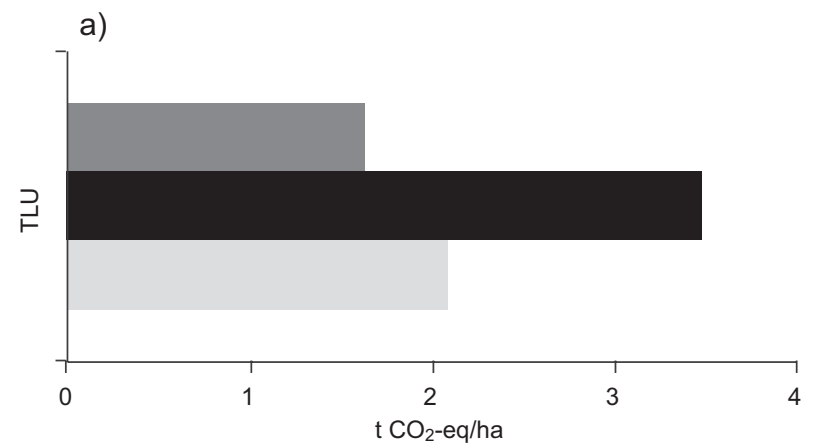

b)

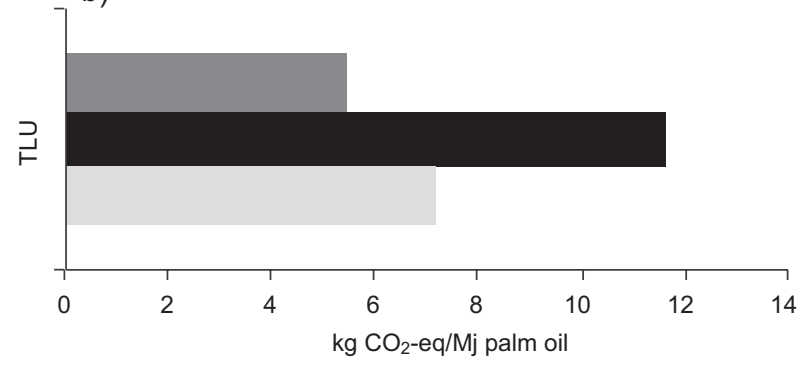

$>20 \mathrm{yr} \quad 5-20 \mathrm{yr} \quad<5 \mathrm{yr}$

Fig. 2. Emissions from carbon stock changes. (a) $t \mathrm{CO}_{2}$-eq/ha, (b) $\mathrm{kg} \mathrm{CO}$-eq/MJ palm oil.

looses its carbon content (indicated by carbon release), often referred to as carbon debts of the plantation. The emissions of GHG from carbon stock changes range between 1.62-3.48 $\mathrm{t} \mathrm{CO}_{2}$-eq/ha (Fig. 2a), and between $5.43-11.62 \mathrm{~kg} \mathrm{CO}$-eq/MJ palm oil (Fig. 2b). This corresponds to the carbon stocks of the oil plantation, which are estimated between 77-87 t C/ha. Notwithstanding this carbon loss due to land conversion, this phenomenon has been anticipated in literature. In fact, the replacement of a rubber estate into an oil palm plantation may result in the production of synthetic rubber from fossil oil elsewhere to meet the world rubber demand, which is the industrial process that produces highest carbon emissions (Hansen et al., 2014). Nevertheless, carbon emissions from the conversion of a rubber estate are much lesser than the conversion of a tropical forest (high carbon stock land) into an oil palm estate (Henson, 2005; Brinkmann Consultancy, 2009; Castanheira, 2014; Hansen et al., 2014). Some studies state that there is no difference in the estimated soil carbon content in rubber and oil palm plantations (e.g., Lai, 2004; Siangjaeo et al., 2011).

Variations (yearly average) in nitrous oxide and the resulting $\mathrm{CO}_{2}$-eq emissions in the oil palm estate from 1986-2009 are shown in Figure 3, which shows that

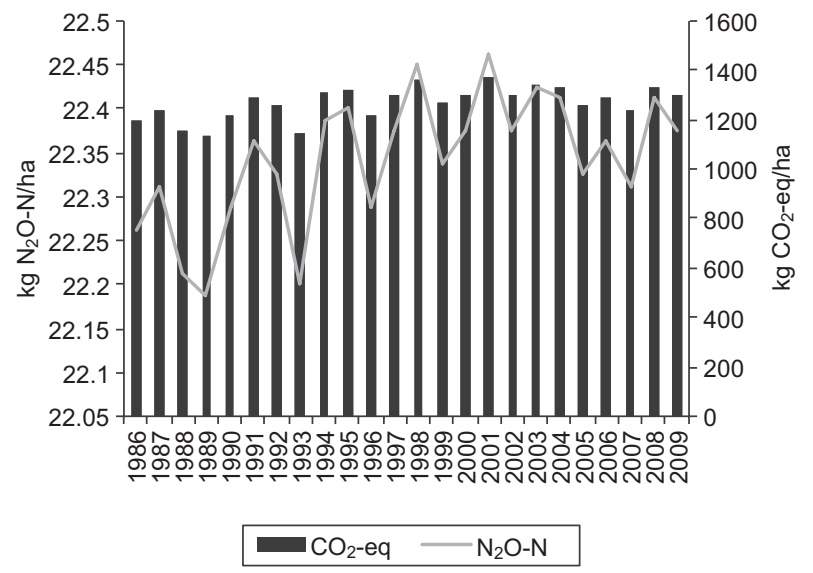

Fig. 3. Nitrous oxide and $\mathrm{CO}_{2}$-eq emissions from 19862009.

there is no significant difference in the yearly variation of emissions. On average, about $22.3 \mathrm{~kg} \mathrm{~N}_{2} \mathrm{O}-\mathrm{N} / \mathrm{ha}$ and $1270.5 \mathrm{~kg} \mathrm{CO}_{2}$-eq/ha were released during the period.

The emissions from $\mathrm{N}$-fertilizer application during the plantation stage of the palm oil production were analyzed for oil palms of different ages at Kempas Estate. Table I shows the amount of $\mathrm{N}$-fertilizer applied and the calculated $\mathrm{N}_{2} \mathrm{O}$ and $\mathrm{CO}_{2}$-equivalent $\left(\mathrm{CO}_{2}\right.$-eq) emissions according to the age of the palms. Overall, the mean values of applied $\mathrm{N}$-fertilizer range between $108-134 \mathrm{~kg} \mathrm{~N} / \mathrm{ha}$, with the release of $19.11-22.17 \mathrm{~kg}$ of $\mathrm{N}_{2} \mathrm{O}-\mathrm{N} / \mathrm{ha}$, resulting in an emission of 1052.26-1209.51 kg of $\mathrm{CO}_{2}$-eq/ha. A slightly greater amount of $\mathrm{N}$-fertilizer was applied for oil palms aged between 5-20 years compared to other categories (i.e., $<5$ years and $>20$ years) (Fig. 4a). For immature palms, empty fruit bunches were typically used as an additional source of fertilizer in addition to $\mathrm{N}$-fertilizer, for assisting the growth of the newly planted palms. Generally, the amounts of $\mathrm{N}$-fertilizer used in the estate are slightly higher than the average in Malaysia, which are of 90 and $105 \mathrm{~kg}$ $\mathrm{N} /$ ha for immature and mature oil palms, respectively, as reported by Schmidt (2007).

Despite little variations in the amount of $\mathrm{N}_{2} \mathrm{O}$ released, the amount of the emission is relatively higher for immature palms $<5$ years, i.e. $22 \mathrm{~kg}$ $\mathrm{N}_{2} \mathrm{O}-\mathrm{N} /$ ha compared to $\sim 19 \mathrm{~kg} \mathrm{~N} \mathrm{~N}_{2} \mathrm{O}-\mathrm{N} /$ ha for mature palms (Fig. 4b), suggesting that $\mathrm{N}_{2} \mathrm{O}$ emissions may decrease as oil palms develop maturely to more than 20 years. Note that the relatively higher $\mathrm{N}_{2} \mathrm{O}$ emission during the immature stage may be attributed to several factors such as 
Table I. Amount of $\mathrm{N}$-fertilizer applied and calculated $\mathrm{N}_{2} \mathrm{O}$ and $\mathrm{CO}_{2}$-eq emissions according to the age of the oil palm (immature and mature).

\begin{tabular}{lccc}
\hline & \multicolumn{3}{c}{ Age of palm (year) } \\
& $<5$ (immature) & 5 -20 (mature) & 20 (mature) \\
\hline $\mathrm{N}$-fertilizer applied (kg N/ha) & 108 & 134 & 118 \\
$\mathrm{~N}_{2} \mathrm{O}$ emissions (kg N2O-N/ha) & 22.17 & 19.31 & 19.11 \\
$\mathrm{CO}_{2}$-eq (kg CO -eq/ha) & 1123.15 & 1209.51 & 1052.26 \\
\hline
\end{tabular}

a)

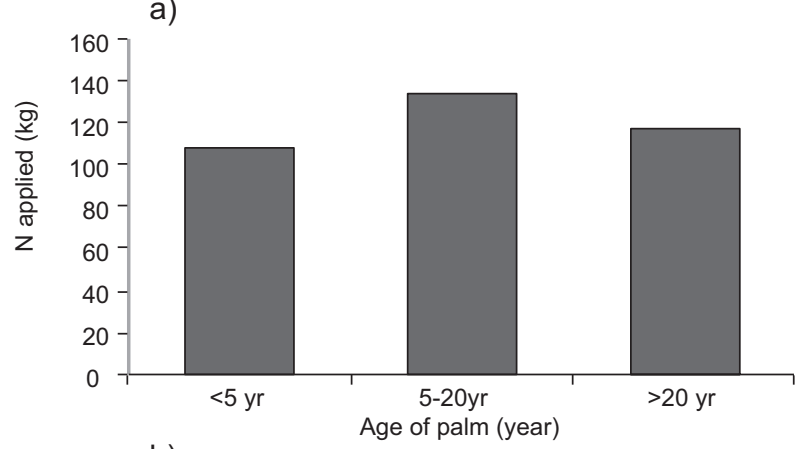

b)

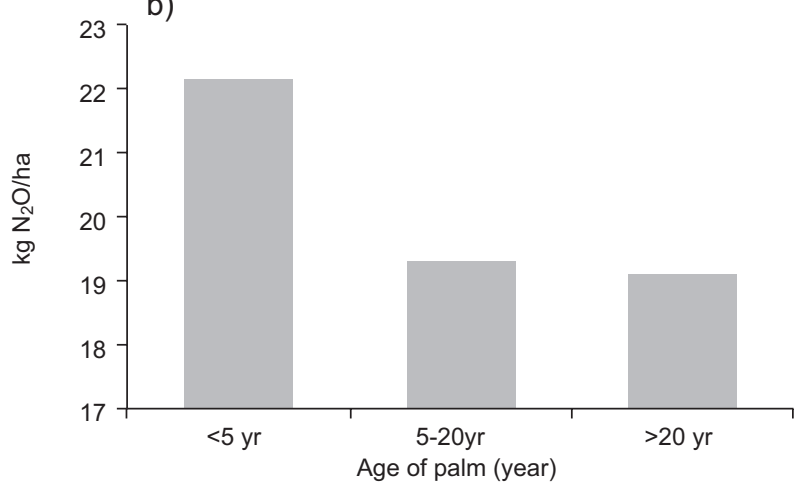

c)

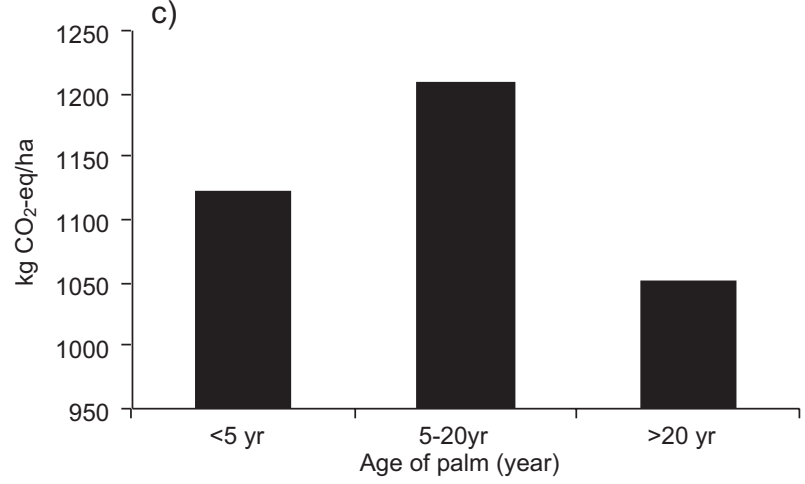

Fig. 4. Amount of (a) N-fertilizer applied (kg); (b) nitrous oxide emission ( $\mathrm{kg} \mathrm{N}_{2} \mathrm{O}-\mathrm{N} / \mathrm{ha}$ ); and (c) $\mathrm{CO}_{2}$-eq emission ( $\mathrm{kg} \mathrm{CO} 2-\mathrm{eq} / \mathrm{ha})$ in Kempas Estate, according to the age of oil palms.

$\mathrm{N}$-fixation processes, return of nitrogen in crop residues and decomposition of biomass (Schmidt, 2007). The high content of $N$ supply during the early stage of palm development is essential to ensure favorable growth conditions and to catalyze the rapid growth of the palm (Sugiyama et al., 1984; Greef, 1994; Sawan et al., 2001). On the other hand, the resulting $\mathrm{CO}_{2}$-eq emission is relatively higher for oil palms aged between 5-20 years (Fig. 4c), which is mainly due to the greater amount of $\mathrm{N}$-fertilizer applied, coupled with the fraction of $\mathrm{N}_{2} \mathrm{O}$ contribution, as discussed earlier. Therefore, it can be seen that the contribution from the $\mathrm{N}$ - fertilizer applied is very important, since it reflects the overall $\mathrm{CO}_{2}$-eq emissions resulting from $\mathrm{N}$-related emissions. Despite this, there is no clear relationship between $\mathrm{N}_{2} \mathrm{O}$ or $\mathrm{CO}_{2}$-eq emissions and the age of the oil palms.

Aside from the N-related emissions, contributions from P-related emissions are also significant to reflect the impact from the use of fertilizers. Similarly, emissions from fuel use (e.g., for internal transportation) are another major input of GHG during the growing stage of the palm oil plantation. Contributions from major inputs of GHG in the estate are illustrated in Figure 5. N- and P-related emissions, as well as fuel emissions contribute to about $79 \%$ and $21 \%$ of total GHG emissions, respectively. Clearly, nitrous oxide has the largest contribution to GHG compared to other major emission inputs during the growing stage.

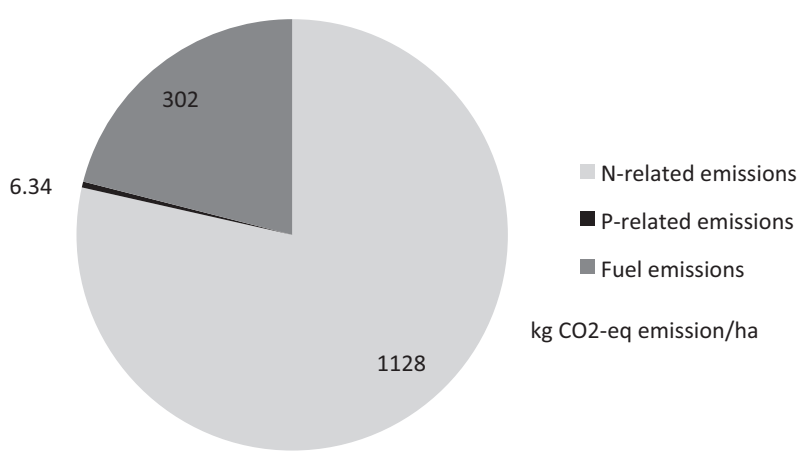

Fig. 5. GHG emissions during tha plantation stage of oil palm production. 
$\mathrm{N}$-related emissions come from various sources including direct and indirect $\mathrm{N}$ emissions, whereby the use of synthetic fertilizer may directly enhance the concentration of nitrogen in soil leading to the release of nitrous oxide through the soil nitrogen cycle prosesses, i.e. nitrification and denitrification (Kusin et al., 2014). Notwithstanding this, $\mathrm{N}_{2} \mathrm{O}$ emissions in the estate (i.e. 19.11-22.17 kg N ha) are in agreement with the values reported by Schmidt (2007) for Malaysian oil palm plantations in general. On the other hand, the resulting $\mathrm{CO}_{2}$-eq emission (i.e., 1052.26-1209.51 kg of $\mathrm{CO}_{2}$-eq/ha) is far below the reported values elsewhere (e.g. Germer and Sauerborn, 2008; Fargione et al., 2008; Wicke et al., 2008; Koh et al., 2011; Page et al., 2011, among others). Brinkmann Consultancy (2009) estimated that the GHG emissions related to the use of fertilizers of between 1000-1500 $\mathrm{kg} \mathrm{CO}_{2}$-eq. $\mathrm{ha}^{-1} \mathrm{yr}^{-1}$.

\section{Conclusions}

The growing stage is considered an important phase throughout the life cycle of palm oil production. This paper has highlighted the significant contribution of this stage, particularly from the use of synthetic fertilizer, to the emission of GHGs. In addition, the impact from land use change on the oil palm plantation development has also been assessed. The findings from this study are twofold:The transformation from a rubber plantation into an oil palm plantation slightly decreases the carbon stocks of the soil (and hence positive carbon emissions).

$\mathrm{NO}_{2}$ is the largest contributor of GHGs during the plantation stage but the amount is within the estimated values for a Malaysian oil palm plantation

Regarding these findings, it is noted that the use of nitrogen fertilizers may be a significant contributor to the emission of GHGs and the loss of carbon content from the plantation during the establishment of the oil palm crop. Therefore, it is likely that the application of nitrogen fertilizer may increase carbon emissions from the conversion of a rubber plantation to an oil palm plantation. However, the emission of $\mathrm{CO}_{2}$-eq in the estate is still low compared to some other reported values elsewhere.

\section{Acknowledgments}

This study was funded through the Long-Term Research Grant Scheme (LRGS) of the Ministry of Higher Education Malaysia (MOHE), project number
LRGS/6375401. The second author wishes to thank University Putra Malaysia for the support from Graduate Research Fellowship Scholarship awarded. Data from Kempas Estate, Sime Darby Plantation Malaysia is greatly appreciated.

\section{References}

Abdullah F. I., 2013. The estimation of carbon dioxide emissions from transportation activities in the palm oil plantation. B. Sc. Thesis, Universiti Putra, Malaysia.

Brinkman Consultancy, 2009. Greenhouse gas emissions from palm oil production. Literature review and proposals from the RSPO Working Group on greenhouse gases. Final report, Brinkmann Consultancy, The Netherlands, 57 pp. Castanheira E. G., H. Acevedo and F. Freire, 2014. Greenhouse gas intensity of palm oil produced in Colombia addressing alternative land use change and fertilization scenarios. Appl. Energ. 114, 958-967.

Chase L. D. C. and I. E. Henson, 2010. A detailed greenhouse gas budget for palm oil production. Int. J. Agric. Sustain. 8, 199-214.

Corley R. H. V. and P. B. Tinker, 2003. The oil palm, 4th ed. Blackwell Science, Oxford, 28 pp.

De Datta S. K., 1995. Nitrogen transformation in wetland rice ecosystems. Fert. Res. 42, 193-203.

Fargione J., J. Hill, D. Tilman, S. Polasky and P. Hawthorne, 2008. Land clearing and the biofuel carbon debt. Science 319, 1235-1238.

Germer J. and J. Sauerborn, 2008. Estimation of the impact of oil palm plantation establishment on greenhouse gas balance. Environ. Dev. Sustain. 10, 697-716.

Giltrap D. L., P. Berben, T. Palmada and S. Saggar, 2014. Understanding and analysing spatial variability of nitrous oxide emission from a grazed pasture. Agr. Ecosyst. Environ. 186, 1-10.

Greef J. M., 1994. Productivity of maize (Zea mays L.) in relation to morphological and physiological characteristics under varying amounts of nitrogen supply. J. Agron. Crop Sci. 172, 317-326.

Hansen S. B., S. I. Olsen and Z. Ujang, 2014. Carbon balance impacts of land use changes related to the life cycle of Malaysian palm oil-derived biodiesel. Int. J. Life Cycle Ass. 19, 558-566.

Henson I. E., 2004. Modelling carbon sequestration and emissions related to oil palm cultivation and associated land use change in Malaysia. MPOB Technology No. 27, Malaysian Palm Oil Board, Kajang, Malaysia, 51 pp. 
Henson I. E., 2005. An assessment of changes in biomass carbon stocks in tree crops and forests in Malaysia. $J$. Trop. For. Sci. 17, 279-296.

Hewitta C. N, A. R MacKenziea, P. Di Carlob, C. F. Di Marco, J. R. Dorseyd, M. Evanse, D. Fowlerc, M. W. Gallagherd, J. R. Hopkins, C. E. Jones, B. Langforda, J. D. Leef, A. C. Lewis, S. F. Limg, J. McQuaide, P. Misztalc, S. J. Mollerf, P. S. Monksh, E. Nemitzc, D. E. Orami, S. M. Owenc, G. J. Phillipsc, T. A. M. Pugha, J. A. Pylej, C. E. Reevesi, J. Ryderc, J. Siongc, U. Skibac and J. Stewarti, 2009. Nitrogen management is essential to prevent tropical oil palm plantations from causing ground level ozone pollution. Sustain. Sci. 106, 18447-18451

IPCC, 2006. IPCC Guidelines for National Greenhouse Gas Inventories (H. S. Eggleston, L. Buendia, K. Miwa, T. Ngara and K. Tanabe, Eds). Agriculture, forestry and other land use. Prepared by the National Greenhouse Gas Inventories Programme. Institute for Global Environmental Strategies, Japan.

IPCC, 2007. Fourth assessment report on climate change 2007. Contribution of Working Group I to the Fourth Assessment Report of the Intergovernmental Panel on Climate Change. Cambridge University Press, Cambridge, United Kingdom and New York, USA.

Millar N., G. P. Robertson, P. R. Grace, R. J. Gehl and J. P. Hoben, 2010. Nitrogen fertilizer management for nitrous oxide $\left(\mathrm{N}_{2} \mathrm{O}\right)$ mitigation in intensive corn (maize) production: An emissions reduction protocol for U.S. Midwest agriculture. Mitigation Adaptation Strategy of Global Change 15, 185-204.

Klaarenbeeksingel F. W., 2009. Greenhouse gas emissions from palm oil production. Brinkmann Consultancy, Hoevelaken, The Netherlands.

Koh L. P., J. Miettinen, S. C. Liew and J. Ghazoul, 2011. Remotely sensed evidence of tropical peatland conversion to oil palm. P. Natl. Acad. Sci. USA 108, 5127-5132.

Kusin F. M., N. I. M. Akhir, F. Mohamat-Yusuff and M. Awang, 2014. Nitrous oxide emission from nitrogen fertilizer application in oil palm plantation of different stages. Int. J. Global Warming, in press.

Lai R., 2014. Soil carbon sequestration in natural and managed tropical forest ecosystems. Journal of Sustainable Forestry 21, 381-388.
Mejan M. A., 2013. Comparison of carbon and organic matter content between highly degraded area and logged over forest for oil palm plantation. B. Sc. Thesis, Universiti Putra Malaysia.

Mosquera J., J. M. G. Hol and J. Dolfing, 2007. Precise soil management as a tool to reduce $\mathrm{CH}_{4}$ and $\mathrm{N}_{2} \mathrm{O}$ emissions from agricultural soils. Report 28. Animal Sciences Group, Wageningen, 42 pp.

MPOB, 2001. Malaysian oil palm statistics 2000, 20th ed. Malaysia Palm Oil Board, 132 pp.

Page S. E., R. Morrison, C. Malins, A. Hooijer, J. O. Rieley and J. Jauhiainen, 2011. Review of peat surface greenhouse gas emissions from oil palm plantations in Southeast Asia. International Council on Clean Transportation, Washington, $80 \mathrm{pp}$.

Sawan Z. M., S. A. Hafez and A. E. Basyony, 2001. Effect of nitrogen and zinc fertilization and plant growth retardants on cottonseed, protein, oil yields, and oil properties. Journal of American Oil Chemists 'Society 78, 1087-1092.

Schmidt J. H., 2007. Life cycle assessment of rapeseed oil and palm oil. Ph. D. Thesis, Aalborg University, DenmarkSchmidt J. H., 2010. Comparative life cycle assessment of rapeseed oil and palm oil. Int. J. Life Cycle Ass. 15, 183-197.

Siangjaeo S., S. H. Gheewala, K. Unnanon and A. Chidthaisong, 2011. Implications of land use change on the life cycle greenhouse gas emissions from palm biodiesel production in Thailand. Energy for Sustainable Development 15, 1-7.

Sugiyama T., M. Mizuno and M. Hayashi, 1984. Partitioning of nitrogen among ribulose-1, 5-bisphosphate carboxylase/oxygenase, phosphoenolpyruvate carboxylase, and pyruvate orthophosphate dikinase as related to biomass productivity in maize seedlings. Plant Physiol. 75, 665-669.

Vandermeer J., G. Smith, I. Perfecto and E. Quintero (coords.), 2009. Effects of industrial agriculture on global warming and the potential of small-scale agroecological techniques to reverse those effects. A report to Via Campesina by The New World Agriculture and Ecology Group. University of Michigan, USA.

Wicke B., V. Dornburg, M. Junginger and A. Faaij, 2008. Different palm oil production systems for energy purposes and their greenhouse gas implications. Biomass and Bioenergy 32, 1322-1337. 